\author{
Dr. sc. Mirko Klarić, associate professor \\ Faculty of Law University of Split
}

\title{
PROBLEMS AND DEVELOPMENTS IN THE CROATIAN LOCAL SELF-GOVERNMENT ${ }^{1}$
}

\author{
UDK: 352 (497.5) \\ Primljeno: srpanj 2017. \\ Pregledni rad
}

\begin{abstract}
Croatian local self -government is organised two levels. First level is local self-government units, cities and municipalities, organised as a polytypic local government units. Those types of local self-government units are firstable responsible for communal affairs and urban planning. On the first level in Croatia are established 550 local units. On the second level are counties, who have responsibility for many decentralised public services on the local level, such as primary health care, elementary education and other local educational services etc, and for coordination between local government units on their own territory. Today in Croatia is 20 counties and capital city Zagreb which also have status as county. Present structure of local self-government has been formatted in 1992 Year, when was abounded earlier system of local self-government. Local units have powers and tasks, dividend into cities and municipalities' one the first level, and counties on the second level. The power of municipalities and cities are in principle equal. Some bigger cities have higher jurisdiction in certain local affairs. All of these local public affairs, managed by local units are limited. One of the questions in future reform of local self government is how to improve organization of local self-government and how local services which they provide can be quality, efficiently and available for affordable price. The main question is can the possibility of decentralisation of local self-government in Croatia improve quality of local public services in local government units? In that sense in this article shall be presented actual problems and developments in Croatian local self-government.
\end{abstract}

Key words: Local self-government system in Croatia, problems and developments

\section{INTRODUCTION}

Local self government in Croatia has organized as a two tier system. On the first level are established municipalities and cities as local self-government units. On the second level are counties. Counties are not regional units, even they was definite in Constitution and in the statutes as type of regional self-government units, but also type of counties units. There are more specific type of local self-government units, with special authorities and tasks. In Croatia existing more than a 550 local

Article is presented on International Scientific Semminar and Summer School „Researching, and Teaching Administrative Science and Public Administration: Croatia, South east Europe, and Beyond; Dubrovnik, Croatia, 10-15., July 2017., Institute of Public Administration, Faculty of Law, University of Zagreb, Faculty of Law, University of Split. 
self-government units (towns and municipalities) on the first level and 22 counties and capital city of Zagreb, which have also status as a county. Originally, this territorial organisation of local self-government is established as a result of reform of local self-government in 1992, when is abounded the old model of municipality system so called "komunalni system (communal system)". Old model of territorial organisation were included approximately hundred of larger municipalities at the same level, on which were divided all territory of Republic of Croatia. Structure of local self-government in that time was monotypic, because all of municipality units had similar structure, with the similar authorities and obligations. Those municipalities have stronger authorities than present local self government units. According to the new territorial organization, which is established as a new model of local self-government, local units are organized in three levels: sub-municipal units, municipalities and cities on the second level, and on the third level is a counties. Public tasks are divided between municipalities and cities on the first level, and counties on the second level. Public authorities and public tasks between cities and municipalities are basically the same. Only large cities have public authorities which are similar to the public authorities which are in jurisdiction of the counties. It was intended to facilitate the functioning of large urban centers with those types of local self-government units.

Many of Croatian public administration scientists and practitioners thinks that present model of local self-government system need changes, because existing model is overcome, and Croatian public administration need fundamental reforms of civil service administration, public services and local self-government. ${ }^{2}$ This paper analyze present situation in Croatia, main problems in functioning of local self-government system, and adequate solutions. In Croatia, there are two main approaches to the reform of local self government. First approach include present model of local self-government, with existing territorial division. Some of the public administration practitioners an scientists thinks that existing model represent optimal solution for organization of local self-government. They think that present system needs some organizational and administrative changes, but the main characteristics of the system must be the same. Other politicians and public experts think that local self-government system in Croatia needs radical changes, which include establishing of two tier system: on the first level larger local selfgovernment units, on the second level $3-5$ regional units, with large fiscal and administrative capacity, which can provide higher economic development of all part of Croatia. New model of local self-government can also help in reducing of local administration, and that can have positive influence in reducing of public spends. This paper will analyzing present situation in Croatia, and possibility of the future development of local self-government in Croatia.

2 Fore example see Koprić, I.: Reforma lokalne i regionalne samouprave u Hrvatskoj: od nemila do nedraga, scientific symposium „Pametna lokalna samouprava“, Novalja, 30. 09. - 01. 10. 2017. 


\section{CONTEMPORARY LOCAL SELF-GOVERNMENT AND NEW TRENDS IN EUROPE}

Local self-government has significant role in political and economic development of many countries. This role is a crucial for development of local communities and development of the whole society. Local democracy with strongly influence of the local community on local self-government units and their political bodies assure democratic development of local communities, and positive influence to the whole society. Economic role assured better economic development of local communities. In different countries are different models of local self-government. Some states have local government which in unified with the same public authorities. ${ }^{3}$ Other states have two levels of local self-government system, or local units on the local level, and regional units on the regional level. For example, Sweden is by tradition unitary state, but decentralized with developed local government. Sweden has two-tier elected local systems, where counties are responsible for public health services, while municipalities manage public tasks relating on education, social services and public utilities. This model provide better functioning of public services and assure quality and availability for the citizens. On the other side, Germany, as a federal state, has two levels of government: federal level and state level (Länder). Länder in Germany has organization of local self-government in two levels: counties (Kreise) and municipalities (Gemeinde). On the first level are counties, who can be metropolitan and non-metropolitan. Metropolitan counties are divided on metropolitan boroughs, while non-metropolitan counties are divided on districts. Metropolitan boroughs have greater powers than districts. This situation illustrate that in Germany existing polytypic organisation of local self-government, which means that complexity of the structure of local government units depends of complexity of local communities. In the case of the larger communities, which cover larger territories, situation with managing the local public tasks are more complexity, especially when we have urban area, which have special public needs, and need quality local public services such as public transport, good organisation of city traffic, kindergartens, etc. Bigger local self-government units have stronger administrative and fiscal capacities, and usually metropolitan type of local selfgovernment units must be able to fulfil some specific local public needs, regarding with complexity of the living in urban area. In England several models of local selfgovernment organisation: two-tier system of local government, unitary authorities, metropolitan authorities and non metropolitan authorities. Two-tier system of local self-government remains that exists two levels of responsibility in managing of public authorities: first at municipal and second on the county level. This model includes consistent separation of public authorities between smaller und larger local self-government units. Unitary authorities remain a unique approach to the local public tasks. Metropolitan authorities' remains local territorial organizations which divides different duties, depending on occasions if these type of public activities

3 Example how we can use local self-government as a tool for democratic consolidation see in Katsamunska, P. - Rosenbaum, A., 2014/15. 
and tasks have significant role for functioning of lower or smaller local public units. Unitary local units were planned as a way of decentralisation and devolution of some public tasks, and a slowly beginning of a process of regionalisation of England. ${ }^{4}$ In France, on the first level of local self-government are introduced municipalities (over 37.000 municipalities existing in France). On the second level are departments with elected councils and council elected presidents (Wollman, H.2004: 639-665). In some states local self-government units have large responsibility in affairs such as education, public health, culture, urban planning, building permits and public utilities with more different communal services. A reform of local self-government is one of the key questions in Europe. Those reforms are different in different countries, but include implementation of many of measures which are connected with neoliberal approach. On the other side, local self-government has significant role in democratic processes in contemporary society. That affects to the political and administrative reforms and lead to increased political power and authority of executive bodies in local self-government units. For example, in France, which is traditionally centralised state, straightening of local self-government has increasing and significant role. Those aims tried to create situation by which more powers gave in hand of local politicians, which can cause high level trust to the local government policy and and local politician. But, research showed that these reforms had no effects upon the relationship between politicians and civil society organisations (Reitan, M. - Gustafsson, K. - Blekesaune, A., 2015: 157 - 160). In analyzing of some indicators, who are important for explanation of local self-government models, can be used some facts like: a) functional decentralisation, b) territorial organisation, c) financial discretion of local self-government, d) horizontal powers relation. Territorial organisation is divided on two variables: number of tiers of elected local and regional governments and territorial fragmentation. Functional decentralisation is value measured by the share of sub - national expenditures in GDP. Financial discretion of local governments is measured by three variables: financial decentralization, the shape of the grant allocation system, local government debt as a percentage in GDP. Horizontal power relations are measured by two variables: position of the mayor in local self-government unit and electoral system in local government unit. According those parameters, countries in South-East Europe, such a Croatia, Macedonia, Slovenia, Albania, Bulgaria, Romania, Ukraine and Moldova has very similar characteristic of local self-government system. Those characteristics are high territorial fragmentation, with low functional and fiscal decentralisation, and concentration of public authority and material sources in central state administration. In those types of local self-government units mayors and county prefects has been elected directly. Executive power is in hands of directly elected mayors and county prefects, and they have dominant role in local politics (Swianiewicz, P., 2014: 292 - 211). Those types of local self-government systems

4 Labour Government was planned that process for England as a process of decentralisation and devolution of public affairs. Probably that was efforts in process of straightening of local democracy and new defining of the role of local political institutions and local public policies in democratic political life of England and the Great Britain. 
it can be presented as a local presidential model, where mostly role have heads of the local self-government units, which control local institutions and resources. They have strong local influence on functioning of local institutions, which are important for the ordinary life in local political community, but they are addicted on central government and centralized resources by their control. Without those resources is very hard to handle infrastructure and many other projects in local community. In that sense, it will be analyze present system of local self-government in Croatia, and possibility for change and decentralisation in future.

\section{LOCAL SELF-GOVERNMENT IN CROATIA-SOME THEORETICAL ASPECTS}

In Croatian administrative theory term local unit or local self-government unit is usually determinate with the term local community. This term were systematic analyzed by Professor Pusić. But local community has a few different meanings, and one of its is community on local level, which has strongly interconnection between members of the community. According to one meaning, local community is form of community which arises when people live and earn in certain area, with specific local interests related with ordinary common needs. They induce various communal activities to fulfill common needs, true various types of local community action. Local community can be also group of people who leaves in some geographic space, represent some kind of organizing community which reflects certain way of life and sometimes takes some forms and ways of collective action. Local community is not a simple social system. Sometime it represents complex system, which is created from more simple social primary systems and subsystems. Some authors think that local community represents type of social community which had territorial character, where on the lowest level arises some local public needs, which must be fulfilled on common way. Pusić argues that local community is not simple social system. It is community with high complexity created form, with primary local social systems and subsystems. Most of local government units are established by logic of legislators and government (Pusić, E., 1981: 2). Political logic can have different motives, and local governments units can be created by other criteria, which does not necessary reflect local community structure. In that sense, local community do not necessarily reflect the structure and organization of local selfgovernment units, because they certainly defined by the government and the political bodies. However, in Croatian administrative theory terms local community and local unit are use oft in the same sense. Basic elements which are common for local communities and local self government units are division of geographic space, population, common activities and public institutions, which can be divided as administrative and political institutions. Political institutions managing a local political process and administrative institutions have major role in implementations of local policies created by local political institutions. 
Local system is made by three types of public organizations. Those organizations are different by their own functions, structures, methods and personal structures. First type of organizations is political institutions. In political institutions citizens in local communities directly or indirectly through elective representatives articulate and create their own interests, resolve interest disputes, make political decisions on direction of development of local communities. Second type of organizations is administrative institutions, which provide local public tasks by local professional public servants, where they solves different public needs by jurisdiction of local self-government units, as a political institutions. Those institutions have some dissimilarity which depends on jurisdiction, types of public tasks and number of local organizations for managing those tasks. They are tool for implementation of local public policies established by representative and executive local bodies. They have special relation to the local political bodies, because they can influence on process of political deceasing (Pusić, E., 2002: $124-125) .^{5}$ Third type of organizations are executive organizations, which are composed by one or more individual politicians or collegial bodies, who have tasks and duties to connect political and administrative elements of local political system (Ivanišević, S., 2008: 20). As a object of special analyses in Croatian administrative theory, existing cities as a type of local self-government units. Some authors in Croatia analyze structure of Croatian cities as local political units in a local system of governing which have some specific characteristics (Pavić, Ž., 2001: 4-11). One of those characteristics is specific relationship in process of governance between three three types of intuitions: political-representative, political-executive and administrative (Pavić, Ž.,1999: 231 -257). Between political-representative and administrative organizations there are executive organization, who trying to have dominant role in local political system (Ivanišević, S., 2008: 43 - 51). One of the principles which can be implemented in explanation of organization of local community is principle of self-organization (Lauc, Z., 2010: 23 - 36). According to this principle, local community, as a basic element for establish of local self-government system, has increasing role for organization of local government. Other principle, which is connected with the first principle, is principle of subsidiary, which is connected with relation between central and local authorities, and division between their powers and authorities. In that sense role of the local public authorities are much significant then the role of the central public authorities. (Bakota, B., 2007: 95 - 122). Principle of decentralization ${ }^{6}$ and principle of democratization ${ }^{7}$ are also significant principle, beyond the principle of subsidiary. ${ }^{8}$ One of the newer principles in organization of local self-government

\footnotetext{
5 There must be stated that relation between local political and administrative institutions goes in to a two relation.

6 Principle of decentralization is connected with principle of subsidiary. Those two principles are important for straightening of local self-government units, and their role in life of public community.

7 The principle of democratisation leads to the better presence of the public community in local and national political process. See Ishiyama, J., 2011: 26 - 67.

8 Those principles represent foundation in organization of Croatian local self-government system. Principle of decentralization is one of the most important principles for establishing efficient local selfgovernment, with different public tasks. At the first sight Croatian local self-government system is a
} 
is also principle of sustainable development (Quental, N. - Lourenco, N. M. - De Silva, F. N: 2009: 15 - 29), which has important influence for development of local communities. ${ }^{9}$ In analyze of organization of Croatian local self-government system in administrative theory has been showed different conceptions: conceptions of administrative decentralizations, conceptions of political decentralizations and marxistic conception of commune. Concept of administrative decentralizations has implementation according United Nations Community development (Cvitan, O., 2003:36 - 38). This theory developing approach that community development is a process where community members are in situation that they can together doing a collective action and generate solutions to common problems (Nederveen Pieterse, J, 2010: 1 - 18). This approach have been recognized as a significant for local social, economic, cultural, political and environmental development of local communities, and it has to been implemented by international institutions such as WHO, OECD, World Bank, Council of Europe and European Union. The United Nations defined community development as a process where community members come together to take collective action and generate solutions to common problems. ${ }^{10}$ Community Development Exchange defines community development as a way of working with local communities. The main thing in a local community is a creation of local society based on justice, equality and mutual respect. Community development includes changing relationships between citizens and politicians and public authorities in local community. Concept of political decentralization is based on logic that some public tasks can be better managed if local public authorities take responsibility to their performing. Here comes at first plan advantages such a specific local public needs and interest in local communities. That is connected with idea of decentralization thru strengthening of local political institutions and bodies. Local communities take responsibility for managing some public tasks and have autonomy in their performing. Concept of subsidiary is one of the principles which are formatted in European Charter of Local Self-government. This principle is one of important principles for political and administrative structure and functioning

highly decentralized because of exist large number of local self-government units. Even is number of local governments large their public authorities and tasks are relatively limited. For a real implementation of principle of decentralization it is necessary to provide higher administrative, fiscal and political capacity in local political institutions, with more autonomy in local powers and tasks. Principle of subsidiary is also important principle, where in conflict between central and local public authorities related on public tasks, advantage have local public authorities, if they can managing those tasks efficient as a central public authorities. Principle of democracy is the third principle, and presents implementation of democratic political institutions in local political affairs. Those institutions are systematic implemented in Croatian local self-government system, especially in elective system. Local self-government units in Croatia are formally totally independent, but they have low fiscal and administrative capacity, and cannot manage larger or complex infrastructure project. So they are very dependent on help of central government bodies and institutions.

9 According to the highly economic standards, which are also adopted in Croatia, this principle is one of the most principles in organization and functioning of local units, and more local communities and local interest organizations and institutions insist on sustainable development based on green economy and efficient sustainable using of natural sources, with high level of protection of environment. More about this topic in Blewitt, J: 2014: 385 - 402.

10 Community development, UNTERM, July, 2014. 
Dr. sc. Mirko Klarić: Problems and Developments in the Croatian Local Self-Government... Zbornik radova Pravnog fakulteta u Splitu, god. 54, 4/2017., str. 807.- 823.

of European Union. According to this principal, all public authorities in doubts of which level is responsible for managing public tasks, accept that lower level of public authorities is responsible for managing of public tasks. This principle in Croatian administrative theory has main role in attempt to create borderers between local and central public authorities. ${ }^{11}$ This principle is important for implementation of decentralization processes in all European countries (Koprić et al, 2014: 315). ${ }^{12}$ Marxistic conception of commune is the most radical conception. This conception emphasizes primacy of local political structure. This conception also presents tools for realization of marxistic doctrine of creation so called "classless society". ${ }^{13}$

\section{DEVELOPMENT OF LOCAL SELF-GOVERNMENT IN CROATIA FROM THE BEGINNING OF THE NINETIES}

It can be detected four phases in development of local self-government in Croatia. First phase is 1990 - 1993, second 1993 - 2001, third phase is 2001 - 2009, and fourth phase is from 2009 till now. In the first phase local self-government had institutional framework from previous socialistic period. Old units acted with the same territorial organization and authorities from the previous system, with the representative and executive bodies. ${ }^{14}$ In that moment, in Croatia has been existed

11 Primary, this principle is connected and related with Catholic social teaching as one of the main principle in catholic social doctrine. For principle of subsidiarity pope Pious XI said: "It is a fundamental principle of social philosophy, fixed and unchangeable, that one should not withdraw from individuals and commit to the community what they can accomplish by their own enterprise and/or industry“. ,The wreaking of civil structures that ensure community participation in decision making was evident both under communist control and uncontrolled capitalism. When existing one centralized ownership and power through the command economy other undermined solidarity true a weakening of the state and promoting of ,economic individualism“. Papa Pious said that supreme authority of the state wad to let local communities handle maters appropriate to them. See Quadragesimo Anno (On Reconstruction of the Social Order), http://www.socialjustice.catholic.org.au/files/Social-Teaching/Quadragesimo_Anno. pdf. Text of encyclicals see on http://www.vatican.va/holy_father/pius_xi/encyclicals/documents/hf_pxi_enc_19310515_quadragesimo-anno_en.htm

12 One of the problems of the Croatian local units is fragmentation, with to many small local selfgovernment units with limited administrative and fiscal capacity, which leads to their weakness, what lover possibility to the other local government units in European Union.

13 In Croatian administrative theory has been developed approach that United Nations Community Development present a way of acting which can assure that deficient material, economic, personal and other resources needs rational and economic spending, according framework determined by central plans, on initiative of central public bodies and under their strong survey. Conception of political decentralization civil service is qualitative different than local self-government. According this conception, local selfgovernment is policy tool for creation political autonomy of local community from central authorities. A local self-government unit does not include possibility that central administration has administrative units on local level. Political decentralization thru strengthening of local self-government authorities and task, at the end leads to dualism of local self-government and local public units of central state authorities. Those two types of units are strictly personal and organizational differenced and separated. Marxistic conception of commune was idealist and unreal, because it lay dawn on hypothesis that is possibly to reduce complexity of managing of local public services and local administrative tasks on level where tgose tasks and services can perform everybody. See Koprić, I., 2006: 253-258.

14 In ex Croatia has been introduced 7 Union of municipalities: Union of municipalities Split - 22 municipalities, Union of municipalities Bjelovar - 10 municipalities, Union of municipalities Varaždin - 
hundred municipalities and capital city Zagreb, as a united municipality ${ }^{15}$ (from 01. January 1991). Representative bodies were communal assemblies, and they elected executive bodies called executive councils with president of executive council. Communal assemblies had significant role in political decision making process, while they had many various authorities and competencies. Assemblies were constituted from three houses: council of so called "joint work"16, socialpolitic council and council of sub-municipal units. In this institutional framework conducted first democratic elections 1990 Year, in May (Koprić, I., 2010 (A): 665666). In second phase it is produced new legislation, which regulated totally new organization of local self-government. Also, territorial organization of country is changed, and new local election was maintained for members of the representative bodies of the local self-government units. ${ }^{17}$

In the second phase are established two autonomic counties, Glina and Knin. Those counties are established for area with a significant Serbian population, but they never had been in force. They were abounded sub-municipality units, called "mjesne zajednice", which had autonomy in managing of local public tasks and services. The property of sub municipality units became property of new local self-government units in first level (cities and municipalities). (Koprić, I., 2010 (A): 666-667). On the first level of local self government system was established municipalities and cities. They have representative bodies (city and municipality councils) and executive bodies (mayors and city governments, municipality mayors and municipality governments). Main public tasks of cities and municipalities were communal services such a waste management, water supply management, maintenance of public areas and local roads, etc. Another task was urban planning and managing of local community development. At the second level were established counties as a local self government units and state administration units on the first level, which cover territory of more cities and municipalities. They

5 municipalities, Union of municipalities Sisak -6 municipalities, Union of municipalities Karlovac -6 municipalities, Union of municipalities Gospić - 5 municipalities and Union of municipalities Zagreb - 19 municipalities. See more in Lozina, D., 2014: 100.

15 In socialistic system, Zagreb was divided on city comunes.

16 In ex Yugoslavia, as a socialistic state, was doctrine that all enterprises and working organizations are property of the working people.

17 New organization of local self-government was highly critiqued by Croatian administrative theory and practice. Special critic was related on institution of county prefect, because that function was not independent from central government and administration. County prefect was head of executive in county, bat also head of state administration. Croatia had semi-presidential system and according the authorities of the President of Republic, counties assembly was electing a county prefect, but he must be confirmed by President. If he was not confirmed by the president, he was not be elected, and election in county assembly must be repeated. At the end of the conflict between the county assembly and the President of the Republic, if the assembly insisted on candidate who is not acceptable President of Republic, assembly is disbanded, and follow new election for new convolution of county assembly. That solution was criticized because it lead in to strong control of local self-government unit by central state authorities. In amended Act of local self-government and local administration was predicted separation position of county prefect as a head of local administration true implementation of institution of county commander. That function had assured that public tasks related on local civil service has been managed and operated by institution which is separated from local self-government institutions and their public tasks. But those institutions had never been implemented in the real life. 
managed some public tasks like urban planning and local development of the county. Also they are appeal instances to the acts which were made by the local units on the first level. The main objection of this model of local self-government was in fragmentation, which include large number of local self-government units, with restricted authorities, and low fiscal and administrative capacity. At the first sight, we are witnessed of tremendous number of local units, but in reality there was a significantly centralization of public authorities in Republic of Croatia (Blažević, R: 2010, $351-366)$.

Third phase becomes with Constitutional changes in 2000. Those changes are created new assumption for further development of local self-government system. Constitution treats counties as units of territorial or regional self-government. Constitution gave many public tasks in jurisdiction of local and regional selfgovernment units, implemented principle of solidarity and subsidiarity and introduced general clause in defining local public tasks and duties. According new Act on local and territorial (regional) self-government, scope of local public tasks is expanded. New legislation also leads practice which exists in other modern countries that the scope of local jobs very wide. With new legal solutions it is completely divided local self-government from state administration on local level. In Act on organization of state administration is implement part which regulate functioning of central administration on local level. From that moment, for managing of public tasks, which are in jurisdiction of central state, are established offices for state administration in counties. County perfect ended to be head of central administration in counties, and counties became exclusively local self-government units or second level. Head of central administration became person which nominated head of the administration in municipality. New prefect was nominated from head of administration in central government, and state administration became independent on county prefect and county administration.

Municipal sub-government had mini reform. In that reform they got a legal personality. In practice, they had the same jurisdiction as before. That jurisdiction depends on politic of local self-government units. According that politics, local public tasks and activities can be transferred to the sub-municipal units. Decision on those questions has local self-government unit. Municipal sub-government units are still local government units important for directly citizenship participation. ${ }^{18}$ However, possibility of their including in local public activities depends on will of local self-government units. From that reason, municipal sub-government in Croatia need more proactive role in local public life (Koprić, I., 2010 (B): 46) a traditional form of citizen participation, sub-municipal government has significant

18 There are several traditional and modern forms of citizens' participation in decision making at local level. For example traditional forms are referendum, citizen's initiative, deliberative assemblies and wider types of sub-municipal governments; such are districts, neighborhoods, parishes. As a new form of traditional participations can be recognized direct elections of mayors, strengthening the leadership role of mayors and other local executives, introduction of recall referendum, mushrooming of independent local political actors. See more in Koprić, I.-Klarić, M., 2014. 
role in local political processes. ${ }^{19}$ In Croatian Context, it is necessary to change regulatory framework of local self-government, and according to the principle of subsidiarity ${ }^{20}$, strengthen local public affairs and institutions. Without reform all system of local self-government which follow process of decentralization and strengthening of local political institutions, it is impossible to renew the role of submunicipal government in Croatian political and administrative system. After reform of local self-government, it will be possible to expand jurisdiction of municipal sub-government which lead to decentralization of local public tasks and activities and will provide better communal services (Klarić, M, 2015).

Fourth phase began with of introduction of new types of local government units, who have some prerogatives as counties. Some bigger cities and cities that are administrative centers of counties got those prerogatives. The jurisdiction was established in some affairs, such are local public schools, local public health, urban planning, process of obtaining of building permits, etc. Second change was novella of elective systems in local and regional self-government units. It was established new system of direct elections of mayors and county prefects. Their mandate became independent from majority in municipal and civil council or assembly of the county (Koprić, I. - Klarić, M, 2015: 397 - 400). Directly elections were increased political position of mayors and county prefects and they became to have independent role in local political institutions. But on the other side, mayors and county prefects must to cooperate with municipality and city councils, and county assemblies if they want to create decisions and managing political and administrative process in local community, like process of creation of local budget, because mayors and county prefects propose and council and county assembly must adopt that act. In 2013 year that reform was supplemented with important novella of Local government Act. According to this Novella, if local representative do not adopt proposal of the local budget they dismisses with the mayor and county perfect, and then follow new local elections for mayors, county prefects and assembly. ${ }^{21}$

\section{CROATIAN LOCAL SELF-GOVERNMENT: PRESENT SITUATION AND POSSIBILITY OF DEVELOPMENT}

Present system of local self-government in Croatia is criticized in Croatian administrative theory and practice. One of main critic is existing territorial structure of our local government, complex structure of local self-government units, with

19 There are several traditional and modern forms of citizens participation in decision making at local level. For example traditional forms are referendum, citizen's initiative, deliberative assemblies and wider types of sub-municipal governments; such are districts, neighborhoods, parishes etc. As a new form of traditional participations can be recognized direct elections of mayors, strengthening the leadership role of mayors and other local executives, introduction of recall referendum, mushrooming of independent local political actors. See more in Koprić, I.-Klarić, M., 2014.

20 For more details which are related with the principle of subsidiarity in Bakota, B., 2007. See also Wollman, H., 2000: 915-936.

21 See Narodne novine No 144/2012. 
many levels of local self-government, sub-municipal, municipal, regional, with some special public authorities of large cities. According to the data, in Croatia are temporarily established 126 cities, 429 municipalities, 20 counties and capital city Zagreb, which held position as local self-government unit and county unit. ${ }^{22}$ Number of sub-government unit cannot be certain, because decision of establishing bringing independently each local self-government unit, and there is no existing public register of sub-municipal government. Local self-government units have low public authorities, which include managing of local communal public services and tasks and public planning. Regional self-government has some prerogatives in public planning, but other prerogatives depend of the central state authorities, and financing of those prerogatives depends on central budget. ${ }^{23}$

Today in Croatia administrative theory and practice existing opinion that is necessary reform and reorganization of local self-government with serious decentralization of public tasks. That reform should follow with the new territorial organization of state and introducing a new model of local self-government units. Those new model must have administrative, fiscal and organizational capacity to manage decentralizing public tasks and efficiently deliver of public services. Some of proposals include completely new organization of local self-government, which include reducing of number of local self-government units, especially small selfgovernment units at the first level of local self-government, which existence depends on financial and administrative help of central public authority. Second, it is need to create qualitative difference between cities and communities, because formal existing criteria are not enough clearly restricted public affairs of those types of selfgovernment units. Third, municipal sub-government should get origin local public authorities, in such enlarged self-government units, and perform public tasks which are important for daily life of local community (Klarić, M.,2015). Present situation where existing municipal sub-government, which is elected directly by the citizens, and does not have any formal prerogatives for managing local public tasks and have very small possibility to influence on political process in local community, make this system formally present in local political life, but in real life usually totally ignored from relevant political factors in local self-government units. The role of municipal sub-government must be more significant, with orientation on local public needs related with the interests of the local community. On regional level, it is necessary to introduce new type of local government unit: region. Region must be crucial

22 See http://polis.iju.hr/lokalna/lokalna/terorg.html. See alsko Zakon o područjima županija, općina i gradova u Republici Hrvatskoj, Narodne novine br. 86/2006, 125/ 2006, 16/2007, 95/2008, 46/2010, 145/2010, 37/2013, 45/2013.

23 Counties managing public tasks in sphere of education, public health, urban planning, public traffic and infrastructure, renewing of public roads, planning and development of network of educational, social, health and cultural institutions, issuing of building permits, etc. Problem is that those activities are financed by central state budget, and original budget of counties are low. For example, it is impossible create of network of public health, because those network depends on public policy of Ministry of health, or network of public education in county, without support of Ministry of science, education and sport. It is very hard to speak about autonomy, when managing of some public affairs, which are gave counties in jurisdiction, depends on will of central state authorities and their public policy. That is one of the main critics of Croatian system of self-government. 
factor for development of bigger local community, and they should cover area with minimal 800.000 people. Their public authorities should be bigger than those who have counties. Also, it would be able that regions manage large amount of public affairs, according to the principle of subsidiary. That include administrative and fiscal autonomy in affairs such a public health, education, culture, science, public planning and economic development.

The other opinion of Croatian experts is that reform of local self-government is possible in present institutional and organizational framework. Some of them think that is need to de-professionalize functions in small self-government units, all local functions make voluntarily, and perhaps unify local public bodies in delivery of public tasks for more small local self-government units (Bakota, B., 2014: 113-128). According to this, it is not important in how many levels local self- government in Croatian local political system exists. More important is creation of that type of local government system, which will be more efficiency and less costs. In that sense, introducing of free performing of public affairs and unifying of public services by local self-government units can also affect positive consequences, without abandonment of existing model of local self-government in Croatia (Babac, B., 2010: 53-84). The idea of regionalization is also criticized as something which is not familiar with Croatian tradition, and which is connected with other, mostly bigger countries. They think that reorganization and decentralization of local selfgovernment system can cause dissolution of Croatian politician and administrative system. For those authors, Cratia is too small to have implemented model of regionalization. On the other side, county are introduced as a local self-government unit in Croatian political and administrative system, as a traditional and historical part of local self-government system, which existing in Croatian administrative space for the centuries, and which can be improved but not changed. ${ }^{24}$

\section{CONCLUSION}

In Croatia are introduced two level of local self-government. On the first level are local self-government units - municipalities and cities. On the second, regional level are counties. It also exist sub-municipal government in Croatian cities and municipalities, as a form of participation of local community in managing of public tasks which have local character and impact. Croatian local self-government has large number of local unit. On the first level are introduced 126 cities and 429 municipalities. On the second level are introduced 20 counties and capital city Zagreb, which has unique status as county. This suggests that the Croatian self-government system is very fragmented. Local public authorities are low, and many of public tasks depend on organizational or fiscal help of central state administration. For that reason it is very hard to implement principle of solidarity and subsidiary, which

24 In that sense, counties have continuity thru the past, and represent good choice for a second level of local self-government system. More about that topic and fears that regionalization of Croatia in not good idea for Croatian national homogeneity in Lozina, D., 2004: 147-155). 
are the main principles in European Charter of local self-government. According these principles, institution of local self-government and municipal sub-government must have stronger administrative, polytypic and fiscal capacity. Present situation in Croatian local self-government are stopping possibility of fully implementation of European Charter of local self-government. It is cleared, that, without fiscal, political and administrative decentralization is practically impossible to implement the main principles, incorporated in European Charter of local self-government, which govern modern organization of local self-government in contemporary countries. These principles are crucial for establishing of modern, democratic and decentralizing system of local self-government, which can fulfill local public needs, and provide efficient local public services.

Today it can be showed a few different approaches in future development of Croatian local self-government system. The main approach follows modern tendencies in other European countries. Those tendencies are strengthening of institutional capacity of local units, reducing their number, strengthening of secondary level of local self-government and decentralization and transfer of public authorities on local self-government units, according to the principle of solidarity. The other aspects of present situation in Croatian local self-government system is a question of relation between local representative and executive bodies, and correlation with professional administrative bodies, which are authorized to provide local tasks and fulfill local needs. There is a gap between representative and executive institutions. This gap is caused with non-existing of informal institutional cooperation between council and executive bodies. The second problem is cooperation between professional administrative bodies and single executive bodies, where executive bodies must assure totally cooperation with administrative bodies, if they want to ensure realization of their public policies. This problem can be managed by effective subordination on leading position of single executive bodies on local administrative bodies, or constitution of collective executive bodies, with political character, which directing of activities of local administrative bodies. Croatian society is in deep political and economic crisis, and soon we can expect a reform in public sector, in order to minimize public spends and rationalize public administration. There is no doubt that in the future will be open question of further reform of local self government, which position should be harmonized with other parts of Croatian political and administrative system.

\section{REFERENCES:}

Babac, B.: Oblikovanje hrvatskog regionalnog političko-upravnog ustrojstva u razmeđu suvremenosti, nacionalne tradicije i europeizacije - prethodni iskazi, Znanstveno-stručni skup "Teritorijalni ustroj i regionalizacija Republike Hrvatske u kontekstu europskih integracija", Pravni fakultet Sveučilišta u Splitu, Split, 2010. 
Dr. sc. Mirko Klarić: Problems and Developments in the Croatian Local Self-Government... Zbornik radova Pravnog fakulteta u Splitu, god. 54, 4/2017., str. 807.- 823.

Bakota, B.: Problemi primjene načela supsidijarnosti, Pravni fakultet u Osijeku, Osijek, 2007.

Bakota, B: Local and Regional Government Reform in Croatia: Subsidiarity and Innovation in an Era of Austerity, in Nunes, Silva, C. - Buček, J: Fiscal Austerity and Innovation of Local Governance in Europe, 2014., pp. 113-128.

Blažević, R.: Upravna znanost, Društveno veleučilište u Zagrebu, Zagreb, 2010.

Blewit, J.: Voluntary Standards and Approaches for Sustainable Communities, in Schmitz - Hoffmann, C. - Schmidt, M. - Hansmann - Hansmann, B. - Palekhov, D.: Voluntary Standard Systems. A Contribution to Sustainable Development, Springer, 2014.

Cvitan, O.: Lokalna samouprava, Veleučilište u Splitu, Split, 2003.

Ishiyama, J. T.: Comparative politics: principles of Democracy and Democratization, April, Wiley-Blackwell, 2011.

Ivanišević, S.: Izvršne institucije u lokalnoj samoupravi, Institut za javnu upravu, Zagreb, 2008.

Katsamunska, P. - Rosenbaum, A.: "Institutionalizing Local Government as an Instrument of Democratic Consolidation: the Cases of Bulgaria and Paraguay", The NISPA Journal of Public Administration and Policy, Vol. VII, No 2, Winter 2014./15.

Klarić, M.: Capacity of sub-municipal government for decentralization, working paper, International Conference „Decentralization policies: Reshuffling the Scene,Institut for Public Administration, Croatia, Research Committee 5, Comparative Studies on Local Government and Politics (IPSA), Research Committee 32 Public Policy \& Administration (IPSA), Croatian Political Science Association, Faculty of Law University of Zagreb, Croatia, Faculty of Political Science University of Zagreb, Dubrovnik, Croatia, 07. - 10. May 2015.

Koprić, I. - Marčetić, G. - Musa, A. - Đulabić, V. - Lalić Novak, G.: Upravna znanost - javna uprava u suvremenom europskom kontekstu, Pravni fakultet Sveučilišta u Zagrebu, Zagreb, 2014.

Koprić, I. (B): „Prijedlozi za reformu lokalne i regionalne samouprave u Hrvatskoj“, Znanstveno-stručni skup Teritorijalni ustroj $i$ regionalizacija Republike Hrvatske $u$ kontekstu europskih integracija, Split, 2010.

Koprić, I.: Različite koncepcije o ulozi lokalnih jedinica, Javna uprava - nastavni materijali, Pravni fakultet Sveučilišta u Zagrebu, Zagreb, 2006.

Koprić, I. (A): „Stanje lokalne samouprave u Hrvatskoj“, Hrvatska i komparativna javna uprava, Vol. 10, No 3, 2010.

Koprić, I. - Klarić, M.: 2014. New Developments in Local Democracy in Croatia and Its Neighbouring Countries, Paper for the IPSA/AISP XXIII World Congress of Political Science Challenges of Contemporary Democracy, Montreal, 19-24 July 2014. Research 
Committee RC 05 Comparative Studies on Local Government and Politics, Panel Contemporary tools for Healing Local Democracy.

Koprić, I. - Klarić, M.: "New Developments in Local democracy in Croatia", Croatian and Comparative Public Administration, Vol 15, No 2, 2015., 389-414.

Lauc, Z.: "Odnos države i samouprave promatran kroz načelo supsidijarnosti”, Anali zavoda za znanstveni i umjetnički rad u Osijeku, sv. 26, Zagreb - Osijek, 2010.

Lozina, D.: Lokalna samouprava, Pravni fakultet Sveučilišta u Splitu, Split, 2004.

Nedeerven Pieterse, J.: Development Theory, Sage Publications Ltd, London 2010.

Pavić, Ž.: Od antičkog do globalnog grada, Pravni fakultet Sveučilišta u Zagrebu, Zagreb, 2001.

Pusić, E.: Komuna i općina, Informator, Zagreb, 1981.

Pusić, E.: Nauka o upravi, Školska knjiga, Zagreb, 2002.

Quental, N. - Lurenco, J. M. - da Silva, F. N.: Sustainable Development Policy: Goals; Targets and Political Cycles, Sustainable Development, January/ February, Vol. 19, Issue 1., pp. 15-29.

Reitan, M. - Gustafsson, K. - Blekesaune, A.: "Do Local Government Reforms Result in Higher Levels of Trust in Local Politicians", Local Government Studies, Vol. 41, No 1, pp. 156-179.

Swianiewicz, P.: “An Empirical Typology of Local Government Systems in Eastern Europe”, Local Government Studies, Vol 40, Issue 2, 2014., pp. 292-311.

Wollman, H.: Local Government Modernization in Germany: Between Incrementalism and Reform Waves, Vol. 78, No 4, 2000., pp. 915-936.

Wollman, H.: "Local Government Reforms in Great Britain, Sweden, Germany and France: Between-Multifunction and Single-Purpose Organizations", Local Government Studies, Vol. 30, Issue 4, 2004., pp. 639-656. 


\section{PROBLEM I RAZVITAK HRVATSKE LOKALNE SAMOUPRAVE}

Hrvatska lokalna samouprava organizirana je na dvije razine. Prvu razinu predstavljaju jedinice lokalne samouprave, gradovi i općine, koje su organizirane kao politipične jedinice lokalne samouprave. Takvi su tipovi lokalne samouprave prije svega odgovorni za komunalne poslove i urbano planiranje. Na prvoj razini u Hrvatskoj postoji 550 lokalnih jedinica. Na drugoj razini nalaze se županije koje su odgovorne za više decentraliziranih javnih službi na lokalnoj razini, prije svega za zdravstvenu skrb, osnovno školstvo i druge lokalne obrazovne institucije, kao i za koordinaciju između jedinica lokalne samouprave na vlastitom području. Danas u Hrvatskoj postoji 20 županija, a glavni grad Zagreb također ima status županije. Sadašnja struktura lokalne samouprave osmišljena je 1992. kada je napušten stariji sistem lokalne samouprave. Lokalne jedinice imaju ovlasti i zadaće koje su podijeljene između gradova i općina na prvoj razini, te županija na drugoj razini. Ovlasti općina i gradova u načelu su jednake. Neki veći gradovi u određenim poslovima imaju višu jurisdikciju. Ovlasti koje imaju lokalne jedinice u javnim poslovima ograničene su. Jedno od pitanja buduće reforme lokalne samouprave jest kako unaprijediti organizaciju lokalne samouprave i kako da lokalne usluge za koje su zadužene dobiju višu kvalitetu, da budu efikasnije i dostupnije pod prihvatljivim troškovima. Glavno je pitanje postoji li mogućnost da decentralizacija lokalne samouprave u Hrvatskoj poboljša kvalitetu lokalnih javnih usluga u jedinicama lokalne samouprave. $\mathrm{U}$ tom smislu, u ovome se članku iznose aktualni problemi i razvoj jedinica lokalne samouprave u Hrvatskoj.

Ključne riječi: sistem lokalne samouprave u Hrvatskoj, problem i razvitak 